\title{
Anthropomorphism in Lyric and Law
}

\author{
Barbara Johnson*
}

Anthropomorphism. n. The attribution of human motivation, characteristics, or behavior to inanimate objects, animals, or natural phenomena.

-American Heritage Dictionary ${ }^{1}$

Through a singular ambiguity, through a kind of transposition or intellectual quid pro quo, you will feel yourself evaporating, and you will attribute to your ... tobacco, the strange ability to smoke you.

-Baudelaire, Artificial Paradises ${ }^{2}$

Recent discussions of the relations between law and literature have tended to focus on prose-novels, short stories, autobiographies, even plays-rather than on lyric poetry. ${ }^{3}$ Literature has been seen as a locus of plots and situations that parallel legal cases or problems, either to shed light on complexities not always acknowledged by the ordinary practice of legal discourse or to shed light on cultural crises and debates that historically underlie and inform literary texts. But,

* Fredric Wertham Professor of Law and Psychiatry in Society, Harvard University. The author would like to thank Shoshana Felman for her stimulating response to an earlier version of this paper.

1. American Heritage Dictionary of the English Language 78 (William Morris ed., 3d ed. 1992).

2. Charles Baudelaire, Les Paradis Artificiels, in 1 Oeuvres COMPlètes 375, 420 (Claude Pichois ed., 1975).

3. See, e.g., Richard A. POSNER, LAW AND Literature: A Misunderstood Relation (1988); RiCHARD H. WEISBERG, THE FAILURE OF THE WORD: THE Protagonist As LAWYER IN MODERN FICTION (1984); Peter Brooks, Storytelling Without Fear? Confession in Law \& Literature, 8 YALE J.L. \& HUMAN. 1 (1996); Robert Weisberg, The Law-Literature Enterprise, 1 Yale J.L. \& Human. 1 (1988); Robin West, Authority, Autonomy, and Choice: The Role of Consent in the Moral and Political Vision of Franz Kafka and Richard Posner, 99 HARV. L. REV. 384 (1985). But see Thomas Grey, Steel Against Intimation: The Motive for Metaphor of Wallace Stevens, Esq., 2 YALE J.L. \& HUMAN. 231 (1990), and Margaret Jane Radin, After the Final No There Comes a Yes: A Law Teacher's Report, 2 YALE J.L. \& HuMAN. 253 (1990), for an interesting discussion of Wallace Stevens, as well as the more extended treatment of Wallace Stevens in Thomas Grey, The Wallace STEvens Case: LaW and THE Practice of POETRY (1991). 
in a sense, this focus on prose is surprising, since lyric poetry has, at least historically, been the more law-abiding or rule-bound of the genres. Indeed, the sonnet form has been compared to a prison (Wordsworth ${ }^{4}$ ) or at least to a bound woman (Keats ${ }^{5}$ ), and Baudelaire's portraits of lyric depression $\left(\right.$ Spleen $\left.^{6}\right)$ are often written as if from behind bars. What are the relations between the laws of genre $^{7}$ and the laws of the state? The present paper might be seen as asking this question through the juxtaposition, as it happens, of two sonnets and a prisoners' association.

More profoundly, though, lyric and law might be seen as two very different ways of instating what a "person" is. There appears to be the greatest possible discrepancy between a lyric "person"-emotive, subjective, individual - and a legal "person"-rational, rights-bearing, institutional. In this paper I will try to show, through the question of anthropomorphism, how these two "persons" can illuminate each other.

My argument develops out of the juxtaposition of two texts: Paul de Man's essay, Anthropomorphism and Trope in the Lyric, ${ }^{8}$ in which I try to understand why for de Man the question of anthropomorphism is at the heart of the lyric, and the text of a Supreme Court opinion from 1993, Rowland v. California Men's Colony. ${ }^{9}$ This case has not become a household name like Roe v. Wade ${ }^{10}$ or Brown v. Board of Education, ${ }^{11}$ and probably with good reason. What is at stake in it appears trivial-at bottom, it is about an association of prisoners suing for the right to have "free cigarette" privileges restored. But the Supreme Court's task is not to decide whether the prisoners have the right to smoke (an increasingly contested right, as it happens, in the United States today). The case has come before the Court to resolve the question of whether their council can be counted

4. William Wordsworth's sonnet, Nuns Fret Not at Their Convent's Narrow Room, contains the lines, "In truth the prison, unto which we doom/ Ourselves, no prison is: and hence to me, In sundry moods, 'twas pastime to be bound/ Within the Sonnet's scanty plot of ground." WILlIAM WORDSWORTH, Nuns Fret Not at Their Convent's Narrow Room, in SELECTED POETRY AND PROSE OF WORDSWORTH 169, 169 (Geoffrey H. Hartman ed., 1970).

5. John Keats's sonnet on the sonnet begins, "If by dull rhymes our English must be chained,/ And, like Andromeda, the sonnet sweet/ Fettered . . . ." JOHN KEATS, On the Sonnet, in SElected Poetry 264, 264 (Paul de Man ed., 1966).

6. One of several poems by Baudelaire entitled Spleen describes a mood produced by or analogized to a rainy day: "Quand la pluie étalant ses immenses traînées/ D'une vaste prison imite les barreaux . . . ." CHARLES BAUdELAIRE, Spleen, in 1 OEUVRES COMPLÈTES, supra note 2 , at 75 .

7. For a suggestive discussion of what it means for a text to obey the law of genre, see JACQUES DERRIDA, The Law of Genre, in ACTS OF LITERATURE 22 (Derek Attridge ed., 1992).

8. PAUL DE MAN, Anthropomorphism and Trope in the Lyric, in THE RHETORIC OF ROMANTICISM 239 (1984).

9. Rowland v. California Men's Colony, 506 U.S. 194 (1993).

10. Roe v. Wade, 410 U.S. 113 (1973).

11. Brown v. Bd. of Educ., 347 U.S. 483 (1954). 
as a juridical "person" under the law. What is at stake, then, in both the legal and the lyric texts is the question: What is a person?

I will begin by discussing the article by Paul de Man, which is one of the most difficult, even outrageous, of his essays. Both hyperbolic and elliptical, it makes a number of very strong claims about literary history, lyric pedagogy, and the materiality of "historical modes of language power."12 Toward the end of his text, de Man somewhat unexpectedly reveals that the essay originated in an invitation to speak on the nature of lyric. But it begins with some general remarks about the relation between epistemology and rhetoric (which can stand as a common contemporary way of framing the relations between law and literature). The transition between the question of the lyric and the question of epistemology and rhetoric is made through the Keatsian chiasmus, "Beauty is truth, truth beauty,"13 which de Man quotes on his way to Nietzsche's short and "better known than understood" 14 essay, Truth and Falsity in an Ultramoral Sense. "What is truth?" Nietzsche asks in that essay's most oftquoted moment: "a mobile army of metaphors, metonymies, and anthropomorphisms." 16 Thus it would seem that Nietzsche has answered, "Truth is trope, trope truth" or "epistemology is rhetoric, rhetoric epistemology." But de Man wants to show in what ways Nietzsche is not saying simply this. First, the list of tropes is, he says, "odd." 17 While metaphor and metonymy are the names of tropes that designate a pure structure of relation (metaphor is a relation of similarity between two entities, while metonymy is a relation of contiguity), de Man claims that anthropomorphism, while structured similarly, is not a trope. It is not the name of a pure rhetorical structure, but the name of a comparison, one of whose terms is treated as a given (as epistemologically resolved). To use an anthropomorphism is to treat as known what the properties of the human are.

12. DE MAN, supra note 8 , at 262 .

13. JOHN KEATS, Ode on a Grecian Urn, in SELECTED POETRY, supra note 5, at 252, 253. This allusion to Keats's Ode on a Grecian Urn stands in for the premise of the compatibility of literary aesthetics with linguistic structures, and of linguistic structures with perceptual or intuitive knowledge, that de Man is often at pains to contest. See his remarks on the pedagogical model of the trivium in PAUL DE MAN, The Resistance to Theory, in THE REsistancE TO THEORY 3, 13-20 (1986).

14. DE MAN, supra note 8, at 239.

15. Friedrich Nietzsche, Truth and Falsity in an Ultramoral Sense, in CRITICAL THEORY SINCE Plato 634 (Hazard Adams ed., 1992). If the Keats poem asserts that aesthetic and epistemological structures are compatible, Nietzche's text, for de Man, is a parody of that claim.

16. Id. at 636 .

17. DE MAN, supra note 8 , at 240. 
"Anthropomorphism" is not just a trope but an identification on the level of substance. It takes one entity for another and thus implies the constitution of specific entities prior to their confusion, the taking of something for something else that can then be assumed to be given. Anthropomorphism freezes the infinite chain of tropological transformations and propositions into one single assertion or essence which, as such, excludes all others. It is no longer a proposition but a proper name. ${ }^{18}$

Why does he call this a proper name? Shouldn't the essence that is taken as given be a concept? If "man" is what is assumed as a given, why call it a proper name? (This question is particularly vexed when the theorist's proper name is "de Man".) The answer, I think, is that "man" as concept would imply the possibility of a proposition. "Man" would be subject to definition, and thus transformation or trope. But proper names are not subjects of definition: They are what they are. If "man" is taken as a given, then, it can only be because it is out of the loop of qualification. It is presupposed, not defined.

Yet the examples of proper names de Man gives are surprising: Narcissus and Daphne. ${ }^{19}$ Nietzsche's triumvirate of metaphor, metonymy, and anthropomorphism then functions like the plot of an Ovidian metamorphosis: From a mythological world in which man and nature appear to be in metaphorical and metonymic harmony, there occurs a crisis wherein, by a process of seamless transformation, a break nevertheless occurs in the system of correspondences, leaving a residue that escapes and remains-the proper name. De Man's discussion of Baudelaire's sonnets will in fact be haunted by Ovidian presences: Echo is lurking behind every mention of Narcissus, while one of the recurring cruxes is whether there is a human substance in a tree. It is perhaps not an accident that the figures that occupy the margins of de Man's discussion are female. If de Man's enduring question is whether linguistic structures and epistemological claims can be presumed to be compatible, the question of gender cannot be located exclusively either in language (where the gender of pronouns, and often of nouns, is inherent in each language) or in the world. By extension, the present discussion of the nature of "man" cannot fail to be haunted by the question of gender.

The term "anthropomorphism" in Nietzsche's list thus indicates that a given is being forced into what otherwise would function as a pure structure of relation. In addition, Nietzsche calls truth an army of tropes, thus introducing more explicitly the notion of power, force, or

18. Id. at 241.

19. See id. 
violence. This is not a notion that can fit into the oppositions between epistemology and rhetoric, but rather disrupts the system. In the text of the Supreme Court decision that I will discuss in a moment, such a disruption is introduced when the opposition on which the case is based, the opposition between natural person and artificial entity, opens out onto the question of policy. There, too, the question is one of truth and power, of the separation of the constative-what does the law say?-from the performative-what does it do?

The bulk of de Man's essay is devoted to a reading of two sonnets by Baudelaire: Correspondances and Obsession, reproduced here. ${ }^{20}$

Correspondances

La Nature est un temple où de vivants piliers

Laissent parfois sortir de confuses paroles;

L'homme y passe à travers des forêts de symboles

Qui l'observent avec des regards familiers.

Comme de longs échos qui de loin se confondent

Dans une ténébreuse et profonde unité,

Vaste comme la nuit et comme la clarté,

Les parfums, les couleurs et les sons se répondent.

Il est des parfums frais comme des chairs d'enfants,

Doux comme les hautbois, verts comme les prairies,

-Et d'autres, corrompus, riches et triomphants,

Ayant l'expansion des choses infinies,

Comme l'ambre, le musc, le benjoin et l'encens,

Qui chantent les transports de l'esprit et des sens. ${ }^{21}$

\section{Correspondences}

Nature is a temple, where the living pillars

Sometimes utter indistinguishable words;

Man passes through these forests of symbols

Which regard him with familiar looks.

Like long echoes that blend in the distance

Into a unity obscure and profound,

Vast as the night and as the light,

The perfumes, colors, and sounds correspond.

There are some perfumes fresh as a baby's skin,

Mellow as oboes, verdant as prairies,

-And others, corrupt, rich, and triumphant,

With all the expansiveness of infinite things,

Like ambergris, musk, benjamin, incense,

That sing the transports of spirit and sense.

20. The translations are mine, made for the purpose of bringing out those aspects of the poems that are relevant to my discussion.

21. BaUdelaire, Correspondances, in 1 OeUVRes COMPLÈTES, supra note 2, at 11, 11. 


\section{Obsession}

Grands bois, vous m'effrayez comme des cathédrales;

Vous hurlez comme l'orgue; et dans nos coeurs maudits,

Chambres d'éternel deuil où vibrent de vieux râles,

Répondent les échos de vos De Profundis.

Je te hais, Océan! tes bonds et tes tumultes,

Mon esprit les retrouve en lui; ce rire amer

De l'homme vaincu, plein de sanglots et d'insultes,

Je l'entends dans le rire énorme de la mer.

Comme tu me plairais, ô nuit! sans ces étoiles

Dont la lumière parle un langage connu!

Car je cherche le vide, et le noir, et le nu!

Mais les ténèbres sont elles-mêmes des toiles

Où vivent, jaillissant de mon oeil par milliers,

Des êtres disparus aux regards familiers. ${ }^{22}$

\section{Obsession}

You terrify me, forests, like cathedrals;

You roar like organs; and in our cursed hearts,

Chambers of mourning that quiver with our dying,

Your De Profundis echoes in response.

How I hate you, Ocean! your tumultuous tide

Is flowing in my spirit; this bitter laughter

Of vanquished man, strangled with sobs and insults,

I hear it in the heaving laughter of the sea.

O night, how I would love you without stars,

Whose light can only speak the words I know!

For I seek the void, and the black, and the bare!

But the shadows are themselves a screen

That gathers from my eyes the ones I've lost,

A thousand living things with their familiar looks.

Both poems end up raising "man" as a question-Correspondances looks upon "man" as if from a great distance, as if from the outside; Obsession says "I," but then identifies with "vanquished man" whose laugh is echoed in the sea.

Correspondances is probably the most canonical of Baudelaire's poems in that it has justified the greatest number of general statements about Baudelaire's place in literary history. The possibility of literary history ends up, in some ways, being the real topic of de Man's essay. De Man will claim that the use of this sonnet to anchor the history of "the symbolist movement" is based on a reading that ignores a crucial element in the poem, an element that, if taken

22. Baudelaire, Obsession, in 1 OeUVRES COMPLÈTES, supra note 2, at 75, 75-76. 
seriously, will not allow for the edifice of literary history to be built upon it.

Correspondances sets up a series of analogies between nature, man, symbols, and metaphysical unity, and among manifestations of the different physical senses, all through the word "comme" ("like"). A traditional reading of the poem would say that the lateral analogies among the senses (perfumes fresh as a baby's skin, mellow as oboes, green as prairies) are signs that there exists an analogy between man and nature and between man and the spiritual realm.

De Man focuses on this analogy-making word, "comme," and notes an anomaly in the final instance. Whereas the first uses of "comme" in the poem equate different things into likeness, the last one just introduces a list of examples-there are perfumes that are rich and corrupt, like musk, ambergris, and frankincense. This is thus a tautology - there are perfumes like ... perfumes. De Man calls this a stutter. He writes, "Comme then means as much as 'such as, for example." 23 "Ce Comme n'est pas un comme comme les autres," writes de Man in a sudden access of French. His sentence performs the stutter he attributes to the enumeration of the perfumes. Listing examples would seem to be quite different from proposing analogies. If the burden of the analogies in Correspondances is to convince us that the metaphorical similarities among the senses point to a higher spiritual unity, then sheer enumeration would disrupt that claim.

There is another, more debatable, suggestion in de Man's reading that attempts to disrupt the anthropomorphism of the forest of symbols. De Man suggests that the trees are a mere metaphor for a city crowd in the first stanza. If the living pillars with their familiar glances are metaphorically a city crowd, then the anthropomorphism of nature is lost. Man is surrounded by tree-like men, not man-like trees. It is not "man" whose attributes are taken on by all of nature, but merely a crowd of men being compared to trees and pillars. De Man notes that everyone resists this reading-as do I-but the intensity with which it is rejected does make visible the seduction of the system that puts nature, god, and man into a perfect unity through the symbol, which is what has made the poem so important for literary history. Similarly, if the last "comme" is sheer enumeration rather than similarity, then the transports in the last line of the poem would not get us into a transcendent realm, but would be like getting stuck on the French transportation system (which, as de Man points out, uses the word "Correspondance" for changes of station within the

23. DE MAN, supra note 8, at 249.

24. Id. 
system). All these tropes would not carry us away into the spiritual realm, but would be an infinite series of substitutions. The echoes would remain echoes and not merge into a profound unity.

If Correspondances is said to place man in the center of a universe that reflects him in harmony with all of nature, the poem Obsession places all of nature and the universe inside the psychology of man. Even the senses are projections. Obsession is the reading of Correspondances as hallucination. While Correspondances was entirely declarative, Obsession is almost entirely vocative. (Interestingly, de Man does not comment on another anomaly in the meaning of the word "comme"-the "comme" in Obsession that means "How!"-which is surprising, since it enacts precisely what he calls "the tropological transformation of analogy into apostrophe."25) Nature is addressed as a structure haunted by the subject's obsessions. Everywhere he looks, his own thoughts look back. For psychoanalytically inclined readers, and indeed for de Man himself in an earlier essay, ${ }^{26}$ Obsession demystifies Correspondances. There is no profound unity in the world, but only, as Lacan would say, paranoid knowledge. ${ }^{27}$ But de Man sees the psychological gloss as another mystification, another anthropomorphism-the very anthropomorphic mystification that it is the duty of lyric, and of lyric pedagogy, to promote. "The lyric is not a genre, but one name among several to designate the defensive motion of understanding." $28 \mathrm{De}$ Man concludes provocatively: "The resulting couple or pair of texts indeed becomes a model for the uneasy combination of funereal monumentality with paranoid fear that characterizes the hermeneutics and the pedagogy of lyric poetry." 29 What comes to be at stake, then, is lyric poetry itself as a poetry of the subject. By juxtaposing lyric and law in this essay, I am implicitly asking whether there is a relation between the "first person" (the grammatical "I") and the "constitutional person" (the subject of rights).

"Only a subject can understand a meaning," claims Lacan. ${ }^{30}$ "Conversely, every phenomenon of meaning implies a subject."

25. Id. at 261 .

26. See Paul de Man, Allegory and Irony in Baudelaire, in ROMANTICISM AND CONTEMPORARY CRITICISM 101 (E.S. Burt et al. eds., 1993). This essay is part of the Gauss Seminar given by de Man in 1967.

27. Lacan writes, "What I have called paranoic [paranoid] knowledge is shown, therefore, to correspond in its more or less archaic forms to certain critical moments that mark the history of man's mental genesis, each representing a stage in objectifying identification." JACQUES LACAN, Aggressivity in Psychoanalysis, in ECRITS 8, 17 (Alan Sheridan trans., 1977).

28. DE MAN, supra note 8, at 261.

29. Id. at 259.

30. LACAN, supra note 27 , at 9.

31. Id. 
What de Man seems to be arguing for here is the existence of a residue of language or rhetoric that exists neither inside nor outside the "phenomenon of meaning." Does lyric poetry try to give a psychological gloss to disruptions that are purely grammatical? Are the periodizations in literary history like "Parnassian" and "Romantic" merely names for rhetorical structures that are not historical? For de Man, Obsession loses the radical disruption of Correspondances by making enumeration into a symptom, which is more reassuring than endless repetition. It is as though de Man were saying that Obsession, despite, or rather because, it is so psychologically bleak, falls back within the pleasure principle - that is, the psychological, the human-whereas Correspondances, which seems so sunny, contains a disruption that goes beyond the pleasure principle. When de Man says that we can get Obsession from Correspondances but not the other way around, this is a way of repeating Freud's experience of the disruption of the pleasure principle in Beyond the Pleasure Principle, a study in which Freud grappled with the very limits of psychoanalysis. ${ }^{32}$ Freud noticed that there were experiences or facts that seemed to contradict his notion of the primacy of the pleasure principle in human life (negative pleasures, the repetition compulsion, the death instinct).$^{33}$ As Derrida has shown, Freud kept bringing the "beyond" back within explainability, but the "beyond" of Freud's theory kept popping up elsewhere. ${ }^{34} \mathrm{He}$ could, in effect, get the pleasure principle to explain its beyond, but not anticipate it. The beyond of the pleasure principle could only exist as a disruption.

De Man makes the surprising claim that Correspondances is not a lyric, but contains the entire possibility of lyric: '“Obsession,' a text of recollection and elegiac mourning, adds remembrance to the flat surface of time in 'Correspondances'-produces at once a hermeneutic, fallacious, lyrical reading of the unintelligible." 35 The act of making intelligible, whether in the lyric or in the terminology of literary history, is for de Man at the end of the essay always an act of "resistance and nostalgia, at the furthest remove from the materiality of actual history." 36 This would mean that "actual history" is what escapes and resists intelligibility. Notice how de Man ends the essay:

32. See Sigmund Freud, Beyond the Pleasure Principle, in 18 THE STANDARd EdTTON OF THE COMPLETE PSYCHOlogiCAL WORKS OF SIGMUND Freud 3, 3-64 (James Strachey ed. \& trans., 1953).

33. See id.

34. See JacQues Derrida, To Speculate-on "Freud," in The Postcard 257, 257-409 (Alan Bass trans., 1987).

35. DE MAN, supra note 8, at 262.

36. Id. 
If mourning is called a "chambre d'éternel deuil où vibrent de vieux râles," then this pathos of terror states in fact the desired consciousness of eternity and of temporal harmony as voice and as song. True "mourning" is less deluded. The most $i t$ can do is to allow for non-comprehension and enumerate nonanthropomorphic, non-elegiac, non-celebratory, non-lyrical, nonpoetic, that is to say, prosaic, or, better, historical modes of language power. ${ }^{37}$

Earlier in the essay, de Man had said of Nietzsche's general analysis of truth that "truth is always at the very least dialectical, the negative knowledge of error." 38 In another essay, de Man speaks of "literature as the place where this negative knowledge about the reliability of linguistic utterance is made available." ${ }^{39}$ Negativity, then, is not an assertion of the negative, but a nonpositivity within the possibility of assertion. The final sentence of Anthropomorphism and Trope in the Lyric is clearly a version of stating negative knowledge. But it is also a personification. "True "mourning"" is said to be "less deluded." ${ }^{\prime 40}$ Underlining the word $i t$ as the agent, he writes, "the most it can do is to allow for non-comprehension." 41 "True mourning" becomes the subject of this negative knowledge. The subjectivizations performed by lyric upon the unintelligible are here rejected, but by a personification of mourning. Is mourning-or rather, "true 'mourning"-human or inhuman? Or is it what makes it impossible to close the gap between "man" and rhetoric? In other words, does this type of personification presuppose knowledge of human essence, or does it merely confer a kind of rhetorical agency? Is it anthropomorphic? Is there a difference between personification and anthropomorphism? Is the text stating its knowledge as if it were a human, or is it just performing the inescapability of the structures it is casting off? Has de Man's conclusion really eliminated anthropomorphism and reduced it to the trope of personification, or is anthropomorphism inescapable in the notion of mourning? Is this what lyric poetry-so often structured around the relation between loss and rhetoric-must decide? or finesse? The least we can say is that de Man has given the last word in his own text to a personification.

\footnotetext{
37. Id.

38. Id. at 242 .

39. DE MAN, supra note 13 , at 10

40. DE MAN, supra note 8 , at 262.

41. Id.
} 
II

That which henceforth is to be "truth" is now fixed; that is to say, a uniformly valid and binding designation of things is invented and the legislature of language also gives the first laws of truth: since here, for the first time, originates the contrast between truth and falsity. The liar uses the valid designations, the words, in order to make the unreal appear as real, e.g., he says, "I am rich," whereas the right designation of his state would be "poor."

-Nietzsche, Truth and Falsity in an Ultramoral Sense ${ }^{42}$

The case of Rowland v. California Men's Colony ${ }^{43}$ is based on a provision in the United States legal code permitting a "person" to appear in court in forma pauperis. The relevant legislation reads in part:

Any court of the United States may authorize the commencement, prosecution or defense of any suit, action, or proceeding, civil or criminal, or appeal therein, without prepayment of fees and costs or security therefor, by a person who makes affidavit that he is unable to pay such costs or give security therefor. ${ }^{44}$

In other words, a "person" may go to court without prepayment of fees if the "person" can demonstrate indigence. The question to be decided by the Court is whether this provision applies to artificial persons like corporations or councils, or whether it is meant to apply only to individuals. In the case that led to Rowland, a council of prisoners in California attempted to bring suit against the correctional officers of the prison for the restoration of the practice of providing free cigarettes for indigent prisoners, which had been discontinued. ${ }^{45}$ They tried to sue in forma pauperis on the ground that the warden forbade the council to hold funds of its own. ${ }^{46}$ The district court found that they had not sufficiently proved indigence. ${ }^{47}$ They were allowed to appeal in forma pauperis in order to enable the court to decide whether the council, as an artificial legal person, is entitled to sue in forma pauperis. The appeals court decided that they were so entitled, ${ }^{48}$ but this conflicted with the ruling by another circuit. ${ }^{49}$

42. NIETZSCHE, supra note 15 , at 635 .

43. Rowland v. California Men's Colony, 506 U.S. 194 (1993).

44. 28 U.S.C. $\$ 1915$ (a) (1966)

45. See Rowland, 506 U.S. at 194.

46. See id.

47. See id.

48. See California Men's Colony v. Rowland, 939 F.2d 854 (9th Cir. 1991), rev'd, 506 U.S. 194 (1993).

49. See FDM Mfg. Co. v. Scottsdale Ins. Co., 855 F.2d 213 (5th Cir. 1988). 
The Supreme Court in Rowland considered whether the provisions for proceeding in forma pauperis should apply only to natural persons, or also to legal persons like associations and councils. The case is therefore about what a person is, and how you can tell the difference between a natural person and an artificial person.

Justice Souter's majority opinion begins with something that in many ways resembles de Man's stutter of infinite enumeration. In order to find out what the legal meaning of "person" is, Souter turns to what is called the "Dictionary Act." The Dictionary Act gives instructions about how to read acts of Congress; it states: "In determining the meaning of any Act of Congress, unless the context indicates otherwise, the word[] 'person' ... include[s] corporations, companies, associations, firms, partnerships, societies, and joint stock companies, as well as individuals." 50 Thus, the word "person" does include artificial entities unless the context indicates otherwise. Next Souter asks, but what does "context" mean? He turns to Webster's New International Dictionary, in which he notes that it means "the part or parts of a discourse preceding or following a 'text' or passage or a word, or so intimately associated with it as to throw light on its meaning." 51 The context, then, is the surrounding words of the act. Of course, Webster's does offer a second meaning for the word context: "associated surroundings, whether material or mental"-a reference not to the surrounding text but to the broader reality or intentionality-but Souter dismisses this by saying, "we doubt that the broader sense applies here." 52 Why? Because "if Congress had meant to point further afield, as to legislative history, for example, it would have been natural to use a more spacious phrase, like 'evidence of congressional intent,' in place of 'context.",53

The word "natural," which is precisely at issue here-since the Court is, after all, trying to find out whether the statute applies only to natural persons-is here applied to an artificial person, Congress, which is personified as having natural intentionality: "If Congress had meant ...." The Court's decision repeatedly relies upon this type of personification; it is as though Souter has to treat Congress as an entity with intentions, even natural intentions, in order to say that Congress could not have meant to include artificial entities in its ruling. There is a personification of an artificial entity, Congress,

50. 1 U.S.C. $\S 1$ (1985).

51. Rowland, 506 U.S. at 199 (quoting Webster's NeW INTERNational COLLEGE DICTIONARY 576 (2d ed. 1942)).

52. Id.

53. Id. at 200 (emphasis added). 
embedded in the very project of interpreting how far the law will allow for artificial entities to be considered persons.

Turning to the Dictionary Act for "person" and to Webster's Dictionary for "context," Souter also notes that he has to define "indicates." The difficulty of doing so pushes him into a volley of rhetorical flourishes: "A contrary 'indication' may raise a specter short of inanity, and with something less than syllogistic force." 54

"Indicates," it seems, means more than nonsense but less than logical necessity. In other words, the task of reading becomes an infinite regress of glossing terms that are themselves supposed to be determinants of meaning. De Man's linguistic stutter returns here as the repeated effort to throw language outside itself. We could read a text, this implies, if only we were sure of the meaning of the words "context" and "indicate." But those are precisely the words that raise the question of meaning in its most general form-they cannot be glossed with any finality because they name the process of glossing itself.

Souter's text, in fact, is most anthropomorphic at those points where the infinite regress of language is most threatening. Congress is endowed with "natural" intentionality in order to sweep away the abyss of reference. Souter's dismissal of the prisoners' association as an "amorphous legal creature" 55 is the counterpart to the need to reinforce the anthropomorphizability of the artificial legal creature, Congress. ${ }^{56}$ Congress, then, is perhaps an example of de Man's "proper name."

Souter's opinion proceeds to detail the reasons why he thinks the in forma pauperis ruling should apply only to natural persons. $\mathrm{He}$ wonders: If an affidavit alleging poverty is required for a person to proceed in forma pauperis, then can an artificial entity plead poverty? Souter again turns to Webster's Dictionary to find that poverty is a human condition, defined as "wanting in material riches or goods; lacking in the comforts of life; needy." ${ }^{57}$ Souter also refers to a previous ruling, which holds that poverty involves being unable to provide for the "necessities of life." $"$ "It is as though only natural persons can have "life," and that life is defined as the capacity to lack

54. Id. at 201.

55. Id. at 204.

56. In a response to the present paper when it was delivered at the Yale Law School, Shoshana Felman made the brilliant suggestion that Souter would have wanted to rewrite Baudelaire's Correspondances as: "Le Congres est un temple où de vivants pilliers laissent parfois sortir de confuses paroles ...." The neoclassical, Parnassian architecture of official Washington, D.C. and the common metaphorical expression "pillars of the community" add piquancy to this suggestion.

57. Rowland, 506 U.S. at 203.

58. Adkins v. E.I. Dupont de Nemours \& Co., 335 U.S. 331,339 (1948). 
necessities and comforts. "Artificial entities may be insolvent," writes Souter, "but they are not well spoken of as "poor." 59 An artificial entity cannot lack the necessities and comforts of life. Only life can lack. The experience of lack differentiates natural persons from artificial persons. To lack is to be human. In a sense, we have returned to de Man's question about mourning. Is lack human, or just a structure? Whatever the case, the Court holds that associations cannot be considered persons for the purpose of the in forma pauperis procedure.

The majority opinion garnered only four votes, however ${ }^{60} \mathrm{~A}$ dissenting opinion, written by Clarence Thomas, argues that there is no reason to restrict the broad definition of "person" to natural persons in this case. ${ }^{61}$ Thomas quotes the Court's view of "poverty" as an exclusively "human condition" and comments:

I am not so sure. "Poverty" may well be a human condition in its "primary sense," but I doubt that using the word in connection with an artificial entity departs in any significant way from settled principles of English usage .... Congress itself has used the word "poor" to describe entities other than natural persons, referring in at least two provisions of the United States Code to the world's "poorest countries"-a term that is used as a synonym for the least developed of the so-called "developing countries." 62

Souter has glossed the word "poor" as though speakers of English could use it only literally. Thomas responds by including the figurative use of "poor" as included within normal usage. The boundaries between natural persons and artificial persons cannot be determined by usage because those boundaries have always already been blurred. In treating Congress as an entity with natural intentions, indeed, Souter has already shown how "natural" the artificial can be.

At another point, Thomas takes issue with Souter's discussion of a case in which an association or corporation is considered a person despite strong contextual indicators to the contrary. In the case of Wilson v. Omaha Indian Tribe ${ }^{63}$ it was decided that "white person" could include corporations because the "larger context" and "purpose" of the law was to protect Native Americans against non-Native American squatters, and that purpose would be frustrated if a "white

\footnotetext{
59. Rowland, 506 U.S. at 203.

60. See id. at 194.

61. See id. at 213 (Thomas, J., dissenting).

62. Id. at 218-19 (Thomas, J., dissenting).

63. Wilson v. Omaha Indian Tribe, 442 U.S. 653 (1979). Both Souter and Thomas discuss Wilson in their Rowland opinions. See Rowland, 506 U.S. at 209; id. at 214 n.1 (Thomas, J., dissenting).
} 
person" could simply incorporate in order to escape the provision of the law. ${ }^{64}$ Souter admits that "because a wholly legal creature has no color, and belongs to no race, the use of the adjective 'white' to describe a 'person' is one of the strongest contextual indicators imaginable that 'person' covers only individuals." ${ }^{\circ 5}$ Justice Thomas argues that if the court "was correct in holding that the statutory term 'white person' includes a corporation (because the 'context' does not 'indicate otherwise') - the conclusion that an association is a 'person' for in forma pauperis purposes is inescapable." ${ }^{66}$ Perhaps another inescapable conclusion is that despite its apparent reference to the physical body, the phrase "white person" is the name, not of a natural, but of a corporate person.

Justice Thomas refutes the reasons Souter has given for finding that artificial entities are excluded from the in forma pauperis provision, noting that there may be sound policy reasons for wanting to exclude them, but that the law as written cannot be construed to have done so. ${ }^{67}$ The Court's job, he writes, is not to make policy but to interpret a statute. "Congress has created a rule of statutory construction (an association is a 'person') and an exception to that rule (an association is not a 'person' if the 'context indicates otherwise'), but the Court has permitted the exception to devour the rule [a nice personification]." ${ }^{68}$ Thomas thus argues that the Court treats the rule as if artificial entities were excluded rather than included unless the context indicates otherwise. "Whatever 'unless the context indicates otherwise' means," writes Thomas, "it cannot mean 'unless there are sound policy reasons for concluding otherwise.",69

Permitting artificial entities to proceed in forma pauperis may be unwise, and it may be an inefficient use of the Government's limited resources, but I see nothing in the text of the in forma pauperis statute indicating that Congress has chosen to exclude such entities from the benefits of that law. ${ }^{70}$

Thus Thomas's two conservative instincts are at war with each other: He would like the Government not to spend its money, but he would also like to stick to the letter of the law.

The question of what counts as a juridical person has, in fact, been modified over time in the legal code. It was in 1871 (significantly,

64. Rowland, 506 U.S. at 214 n.1 (Thomas, J., dissenting) (discussing Wilson, 442 U.S. at 725).

65. Id. at 209 .

66. Id. at $214 \mathrm{n} .1$ (Thomas, J., dissenting).

67. See id. at 215-16 (Thomas, J., dissenting)

68. Id. at 222 (Thomas, J., dissenting).

69. Id. at 214 (Thomas, J., dissenting).

70. Id. at 215-16 (Thomas, J., dissenting). 
perhaps, at the beginning of the end of post-Civil War Reconstruction) that Congress first passed the so-called Dictionary Act, in which it stated that the word "person" "may extend and be applied to bodies politic and corporate."71 More recently, the question of fetal personhood has been debated, not only in the Roe $v$. Wade decision, in which it was decided that a fetus was not a legal person, ${ }^{72}$ but also in Weaks v. Mounter, in which it was decided that a fetus was a person who could sue for intrauterine injuries, but only after birth. ${ }^{73}$ Recently, the question of granting patents for forms of life like oilslick-eating bacteria or genetically altered mice has raised the question of whether a hybrid between humans and close animal relatives can be patented. ${ }^{74}$ And more recently, of course, the question of the ethics and legality of cloning humans has been raised. ${ }^{75}$ The law has reached another crisis about the definition of "person." In an article on constitutional personhood, Michael Rivard writes:

Current law allows patents for genetically-engineered animals but not for human beings. Humans are not patentable subject matter because patents are property rights, and the Thirteenth Amendment forbids any grant of property rights in a human being. Nevertheless, this exclusion for humans will prove impossible to maintain: within ten to thirty years, or perhaps sooner, advances in genetic engineering technology should allow scientists to intermingle the genetic material of humans and animals to produce human-animal hybrids .... It may soon be possible to patent-and to enslave - human-animal hybrids who think and feel like humans, but who lack constitutional protection under the Thirteenth Amendment. ${ }^{76}$

Recall that the Thirteenth Amendment is the amendment that abolishes slavery. The constitutional protection against slavery operates as a constraint on the patent office, but it does so in a paradoxical way. The fear of reinstituting something like slavery, or property in humans, is a reaction to, but also a sign of, what must be

71. Act of Feb. 25,1871 , ch. $71, \S 2,16$ Stat. 431.

72. See Roe v. Wade, 410 U.S. 113 (1973).

73. See Weaks v. Mounter, 493 P.2d 1307 (Nev. 1972).

74. In Diamond v. Chakrabarty, 447 U.S. 303 (1980), the Supreme Court ruled that a "live, human-made micro-organism is patentable subject matter." In 1989, Harvard University received a patent for a genetically altered mouse or "oncomouse." See SHELDON KROMSKY, BIOTECHNICS AND SOCIETY: THE RISE OF INDUSTRIAL GENETICS 44-45 (1991); Ned Hettinger, Patenting Life: Biotechnology, Intellectual Property, and Environmental Ethics, 22 B.C. ENVTL. AFF. L. REV. 267 (1995).

75. See Gina Kolata, Scientist Clones Human Embryos and Creates an Ethical Challenge, N.Y. Times, Oct. 24, 1993, at Al.

76. Michael D. Rivard, Toward a General Theory of Constitutional Personhood: A Theory of Constitutional Personhood for Transgenic Humanoid Species, 39 UCLA L. REV. 1425, 1428-29 (1992). 
an ongoing research goal to come as close as possible to creating the ownable, enslavable human. ${ }^{77}$

Constitutional personhood has in fact often been defined in proximity to slavery. In the most notorious example, the Dred Scott case of $1857,{ }^{78}$ we find many of the same issues of legal standing, personhood, and interpretation that were present in Rowland. This case, too, is about who has the right to sue. In Dred Scott the operative word is "citizen" rather than "person," but as Justice Taney put it in his prefatory remarks, "The words "people of the United States' and 'citizens' are synonymous terms, and mean the same thing." 79 Many of the same issues of legal rights and protections, as well as legal interpretation, arise. Dred Scott, whose original legal status was that of a slave, was taken by his master to free territory. Upon his return to Missouri, he sued for his freedom, arguing that his stay in free territory made him free. Justice Taney ruled not only that Scott was not free, but that he was not a citizen with the right to sue, and indeed that persons of African descent had no rights that the white man was bound to respect. Taney derives this opinion from the words of the Constitution and of the Declaration of Independence. He quotes the words of the Declaration:

We hold these truths to be self-evident: that all men are created equal; that they are endowed by their Creator with certain inalienable rights; that among them is life, liberty, and the pursuit of happiness; that to secure these rights, governments are instituted, deriving their just powers from the consent of the governed. ${ }^{80}$

Then Taney goes on to say, "The general words above quoted would seem to embrace the whole human family, and if they were used in a similar instrument at this day would be so understood." 81 In other words, he sees as his task only to interpret the meaning of the law, not to bring it up to date, which would, in a sense, be a policy decision. He goes on to explain why the Declaration of Independence could not have meant what it says:

It is too clear for dispute that the enslaved African race were not intended to be included and formed no part of the people who framed and adopted this Declaration; for if the language, as

77. See A. Leon Higginbotham, Jr. \& Barbara Kopytoff, Property First, Humanity Second: The Recognition of the Slave's Human Nature in Virginia Civil Law, 50 OHIO ST. L.J. 511, 520 (1989) ("The humanity of the slave, requiring that he be treated with the care due other humans and not like other forms of property, became part of the owner's property rights.").

78. Dred Scott v. Sandford, 60 U.S. (19 How.) 393 (1857).

79. Id. at 404 .

80. Id. at 410

81. Id. 
understood in that day, would embrace them, the conduct of the distinguished men who framed the Declaration of Independence would have been utterly and flagrantly inconsistent with the principles they asserted.... Yet the men who framed this Declaration were great men - high in literary acquirements, high in their sense of honor and incapable of asserting principles inconsistent with those on which they were acting. ${ }^{82}$

Thus, enslaved African Americans could not have been included among the people, because the Framers were great men, and could not have been inconsistent. Notice how literature is brought in to confirm their greatness: They were high in literary attainments; they did not use words lightly. The greatness of white men requires that they not be inconsistent. In order for the founding fathers to maintain their greatness, the African American has to have no rights. If the United States has reached a crisis over the rights of Africans, it is more important to maintain the consistency of the founding fathers than to enact the literality of their words. The phrase "all men," like the word "man," introduces a crisis or a stutter if it is opened as anything other than a given.

This split between the Framers and their words-this advance of the words over their understood meaning-is also pointed out by Don Fehrenbacher in his book Slavery, Law, and Politics. ${ }^{83}$ He (along with many others) notes that the Constitution never uses the word "slavery" even in the three clauses that apply to that institution, as if the Framers obscurely knew that the institution would disappear. The most subtle sign of that nudging into disappearance is a revision of the Fugitive Slave Clause. ${ }^{84}$ Fehrenbacher writes:

Perhaps most revealing of all was a last-minute revision of the fugitive slave clause. As it came from the committee of style, the clause began: "No person legally held to service or labour in one state, escaping into another, shall ... be discharged from service ...." The revised version read: "No person held to service or labour in one state, under the laws thereof." Because of its contextual ambiguity, the word "legally" would have permitted the inference that the Constitution explicitly affirmed the legality of slavery. The framers, in shifting to the phrase "under the laws thereof," lent strong support to those anti-slavery spokesmen of a later day who would insist that slavery was

82. Id.

83. Don E. Fehrenbacher, Slavery, Law, and Politics: The Dred Scott Case in Historical PERPECTIVE (1981).

84. U.S. CONST, art. IV, \& 2, cl. 3. 
without national existence and strictly the creature of local law. ${ }^{85}$

It is amazing what a difference such a small change can introduce, by shifting an implicit endorsement of the legality of slavery to a mere description of its legality in some states. Fehrenbacher ends his discussion by saying, "it is as though the framers were half-consciously trying to frame two constitutions, one for their own time and the other for the ages, with slavery viewed bifocally - that is, plainly visible at their feet, but disappearing when they lifted their eyes." ${ }^{\prime 86}$ A written text of law can thus contain a double intention, the trace of a compromise between differing opinions. No wonder interpreting the law's intention is so complicated. That intention can always already be multiple. The distinction Justice Thomas made between interpreting the law and making policy cannot hold if the law's ambiguity allows for the possibility that the policy it governs will change.

\section{III}

The "inhuman" is not some kind of mystery, or some kind of secret; the inhuman is: linguistic structures, the play of linguistic tensions, linguistic events that occur, possibilities which are inherent in language-independently of any intent or any drive or any wish or any desire we might have .... If one speaks of the inhuman, the fundamental non-human character of language, one also speaks of the fundamental non-definition of the human as such.

-Paul de Man, Benjamin's "The Task of the Translator"

Only smoking distinguishes humans from the rest of the animals. -Anonymous (quoted in Richard Klein, Cigarettes Are Sublime $)^{88}$

The case of Rowland v. California Men's Colony was ostensibly about whether a council of inmates could sue prison officials in forma pauperis to get their cigarettes back. The details of the case seemed irrelevant to the question of whether an artificial person has the right to sue in forma pauperis. Yet perhaps some of those details deserve note. Is it relevant that the suit to decide this question was brought by a council of inmates? The phenomenon of the inmate civil suit has

\footnotetext{
85. Fehrenbacher, supra note 83 , at 14.

86. Id. at 15.

87. PAUl DE MAN, Benjamin's "The Task of the Translator," in THE ResistanCE TO THEORY, supra note 13 , at 73,96 .

88. Richard Klein, Cigarettes ARe Sublime 23 (1993).
} 
grown to the point where the case law may very well be transformed by it. In a 1995 study of inmate suits in California, it was reported that "[f]or the last fourteen years at least, the federal courts have faced a growing caseload and workload challenge posed by inmate cases. . . By 1992, these filings numbered nearly 30,000, and constituted $13 \%$ of the courts' total civil case filings nationwide." 89 The majority of these suits are filed in forma pauperis. ${ }^{90}$ The Supreme Court's decision may well have been affected by what Clarence Thomas calls "policy considerations."

If prisoners are affecting the nature of civil proceedings, they are also, at least figuratively, affecting theoretical discussions about the nature of rational choice and the evolution of cooperation. The celebrated "Prisoner's Dilemma" has been central to questions of selfinterest and social goods since it was introduced by Albert Tucker in $1950 .{ }^{92}$ Max Black has even entitled his discussion of these issues The "Prisoner's Dilemma" and the Limits of Rationality. ${ }^{93}$ Why is it that the theoretical study of rational choice has recourse to "man" conceived as a prisoner? Does this have anything to do with the poets' tendency to see the sonnet form as a prison?

And is it by chance that Rowland is about cigarettes? On the one hand, it seems paradoxical that the council has to demonstrate its indigence in order to pursue its suit against the prison directors for depriving them of cigarettes; in prisons cigarettes function as a form of currency. On the other hand, it seems fitting that the personhood of the association is the counterpart to the humanity of the inmates, which, as common wisdom (quoted above, second epigraph) would have it, is demonstrated by the act of smoking. The prisoners would thus, in a very attenuated way, be suing for their humanity. As Richard Klein has wittily shown, smoking serves no function other than to enact a structure of desire-of human desire for self-transcendence, for repetition, for bodily experience corresponding to something other than the "necessities of life" required for existence alone: in short, desire for the sublime. ${ }^{94}$

89. Kim Mueller, Inmates' Civil Rights Cases and the Federal Courts: Insights Derived from a Field Research Project in the Eastern District of California, 28 CREIGHTON L. REV. 1255, 125859 (1995). In the Eastern District of California, inmates' civil rights actions constituted nearly $30 \%$ of the case filings. See id. (California Men's Colony is not in the Eastern District; it is in San Luis Obispo, in the Central District.)

90. See id. at $1276,1281$.

91. Rowland v. California Men's Colony, 506 U.S. 194, 217 (1993) (Thomas, J., dissenting).

92. See Ronald J. Gilson \& Robert H. Mnookin, Disputing Through Agents: Cooperation and Conflict Between Lawyers in Litigation, 94 CoLUM. L. REV. 509,514 n.15 (1994) (discussing how Tucker created the original version of the game).

93. MAX BLACK, The "Prisoner's Dilemma" and the Limits of Rationality, in PERPLEXITIES: Rational ChOICE, THE Prisoner's Dilemma, MetaPhor, POETIC AMBiguity, AND OTHER PUZZles 112 (1990); see also RoBERT AXELROD, THE EVOLUTION OF COOPERATION (1984).

94. See KLEIN, supra note 88. Klein notes, incidentally, that Baudelaire is one of the first 
The sublimity of cigarettes has become increasingly imperceptible in the United States, with the rise of smoking bans and health warnings, but Klein makes it clear that cigarettes were always good because they were bad. "Cigarettes are bad. That is why they are good-not good, not beautiful, but sublime." 95 They were not, in fact, always the un-American objects they appear to be today: "Whenever the society needed more soldiers ... smoking cigarettes changed its value and became not only laudatory but patriotic." ${ }^{96}$ In addition, cigarettes occupy a strange niche with respect to the United States government. Recent debates about whether or not nicotine is a drug that should be regulated by the Food and Drug Administration (FDA) have been conducted on the assumption that the FDA, an agency of the executive branch of government, is the appropriate body to deal with this vexed question. But in fact, as John Jevicky has argued, Congress has repeatedly reserved for itself the right to regulate tobacco products, except insofar as they are labeled for a medicinal purpose. ${ }^{97}$

Both a drug and not a drug, both legal and banned, a soldier's comfort and a veteran's cancer, the relation between cigarettes and "natural persons" raises the question of what "natural" means. But cigarettes have raised the question of the rights of "corporate persons" in interesting ways, too, through recent wrongful death suits against tobacco companies. In attempting to keep the records of damaging research about nicotine out of the courts by appealing to attorney-client privilege, the defendant corporations are testing the limits of corporate personhood.$^{98}$ In other words, tobacco is located precisely at crisis points in the definition of both natural and artificial persons.

If anthropomorphism relies on the givenness of "man" for its rhetorical effect, tobacco seems well placed both to instate and to undercut what counts as "human." Indeed, in one of Richard Klein's most powerful and sweeping observations, tobacco, a Native American product, is what brought modern Western man into being:

French writers to use the word "cigarette" in print (in his Salons de 1848). See id. at 8.

95. Id. at 2.

96. Id. at 4 .

97. See John E. Jevicky, FDA's Regulation of Tobacco Products: A Flagrant Disregard of

Congressional Intent, 24 N. KY. U. L. REV. 535 (1997). Jevicky explains:

In 1906, Congress's enactment of the Pure Food and Drugs Act gave no authority over tobacco products to FDA's predecessor, the Bureau of Chemistry. In 1914, the Bureau of

Chemistry decided that, even though smoking was already widespread, tobacco not labeled

for a medicinal purpose did not fall within the jurisdiction of the Pure Food \& Drugs Act.

Id. at 537. The analogy with recent discussions of the legality of marijuana is striking.

98. See Clay Calvert, Smoking Out Big Tobacco, 24 PEPP. L. REV. 391 (1997); Christine Hatfield, The Privilege Doctrines-Are They Just Another Discovery Tool Utilized by the Tobacco Industry to Conceal Damaging Information?, 16 PACE L. REV. 525 (1996). 
The introduction of tobacco into Europe in the sixteenth century corresponded with the arrival of the Age of Anxiety, the beginning of modern consciousness that accompanied the invention and universalization of printed books, the discovery of the New World, the development of rational, scientific methods, and the concurrent loss of medieval theological assurances. The Age of Anxiety gave itself an incomparable and probably indispensable remedy in the form of tobacco; it was an antidote brought by Columbus from the New World against the anxiety that his discoveries occasioned in the Eurocentered consciousness of Western culture, confronted by the unsuspected countenance of a great unknown world contiguous with its own. The paradoxical experience of smoking tobacco, with its contradictory physical effects, its poisonous taste and unpleasant pleasure, was enthusiastically taken up by modernity as a drug for easing the anxiety arising from the shock of successive assaults on old certainties and the prospect of greater unknowns. ${ }^{99}$

In the article cited above by Michael Rivard, Toward a General Theory of Constitutional Personhood ${ }^{100}$ the drive to formulate a clear-cut definition of what would count as a constitutional person appears to be operating under the imperative precisely to counter the "assaults on old certainties and greater unknowns" caused by the possibility of transgenic humanoid species. But in its nearly one hundred pages of argument for an ironclad "personhood presumption theory," the fundamental definition of the constitutional person turns out very much to resemble de Man's stutter or Souter's abyss of reference. Rivard quotes Daniel Dennett quoting Harry Frankfurt elucidating the fundamental characteristic of self-awareness:

Besides wanting and choosing and being moved to do this or that, men may also want to have (or not to have) certain desires and motives. They are capable of wanting to be different, in their preferences and purposes, from what they are. ${ }^{101}$

This is paradoxical enough to be true (and reminiscent of Lacan's theory of the mirror stage ${ }^{102}$ ), but it is hard to see how the capacity for self-difference can be tested and legislated as a basis for constitutional personhood.

99. KLEIN, supra note 88 , at 27 .

100. Rivard, supra note 76.

101. Rivard, supra note 76, at 1486 (quoting DANIEL DENNETT, BRAINSTORMS 281 (1981) (quoting Harry Frankfurt, Freedom of the Will and the Concept of a Person, in WHAT IS A PERSON? 127 (M. Goodman ed., 1988)).

102. See LACAN, The Mirror Stage As Formative of the Function of the I As Revealed in Psychoanalytic Experience, in ÉCRITS, supra note 27, at 1. 
In Rivard's view, "corporations would be presumed constitutional nonpersons," especially for liberty-related rights, unless the corporation could rebut its nonperson status by showing specific natural persons "who would be affected if the corporation were denied these rights." 103 This is the opposite of the Dictionary Act, which considers a corporation a person "unless the context indicates otherwise." Rivard is arguing for the rights of new biological species who can pass the "self-awareness test" (wanting to be different from what one is), and he claims that corporations, by their nature, do not pass this test.

But the question of the nature of corporations as persons has never been a simple one, as Rivard admits. Gregory A. Mark has outlined in detail the history of corporate personhood. ${ }^{104}$ The relation between corporations and the natural persons who compose them has grown more complicated over time. In most discussions of the matter, it is the "natural" person that functions as the known quantity, and the "artificial" that is either just an "aggregate" of natural persons, or a fiction created by the state, or a mere metaphor, or actually resembles (is like, to return to the Baudelairean word) a natural person in that it has a "will" of its own. Such a corporate will is a form of agency separate from that of the natural corporators, who exist behind the "veil" of the corporation. ${ }^{105}$

Much of Mark's article concerns the exact rhetorical valence of this personification:

American law has always recognized that people's activities could be formally organized and that the resulting organizations could be dealt with as units. Personification, however, is important because it became far more than a quaint device making it possible for the law to deal with organized business entities. In American legal and economic history, personification has been vital because it (1) implies a single and unitary source of control over the collective property of the corporation's members, (2) defines, encourages, and legitimates the corporation as an

103. Id. at 1501-02.

104. See Gregory A. Mark, The Personification of the Business Corporation in American Law, 54 U. CHI. L. REV. 1441 (1987).

105. The history of theories of corporate personhood is summarized in Mark, see id. at 144183 , and in Rivard, see Rivard, supra note 76, at 1450-65. The term "veil" used to refer to the personified appearance of the corporation has long been used in rhetorical treatises to describe the nature of allegorical representation. See, e.g., PIERRE FonTANIER, LES Figures DU DISCOURS (1968). Allegory "consists of a proposition with a double meaning, literal and spiritual at once, through which one presents a thought under the image of another thought, capable of rendering it more striking or more perceptive than if it had been presented without any sort of veil." Id. at 144 (translation by the author) (emphasis added). In Rowland, Justice Souter speaks of "piercing the veil" of the association in order to see the individuals who compose it. See Rowland v. California Men's Colony, 506 U.S. 194, 195, 207 (1993). A veil, then, is a sign in both legal and literary language that a figurative dimension must be taken into consideration. 
autonomous, creative, self-directed economic being, and (3) captures rights, ultimately even constitutional rights, for corporations thereby giving corporate property unprecedented protection from the state. ${ }^{106}$

Mark takes seriously the role of language in the evolving history of the corporation. Philosophers and legislators have gone to great lengths to minimize the rhetorical damage, to eliminate personification as far as possible, but he asserts that it is not just a figure of speech to speak of a corporation's "mind," or even its "life." "Practical experience, not just anthropomorphism, fixed the corporate mind in the management hierarchy." ${ }^{107}$ The corporation resembles a human being in its capacity to "take resolves in the midst of conflicting motives," to "will change." 108 Yet the analogy is not perfect. The corporation, for example, unlike its corporators, is potentially immortal. The effect of personification appears to derive its rhetorical force from the ways in which the corporation resembles a natural person, yet the corporation's immortality in no way diminishes its personification. When Mark says that it is "not just anthropomorphism" that underpins the agency of the corporation, ${ }^{109}$ he still implies that we can know what anthropomorphism is. But his final sentence stands this presupposition on its head. Far from claiming that a corporation's characteristics are derived from a knowable human essence, Mark suggests that what have been claimed to be the essential characteristics of man (especially "economic man") have in fact been borrowed from the nature of the corporation:

Personification with its roots in historic theological disputes and modern business necessity, had proved to be a potent symbol to legitimate the autonomous business corporation and its management. Private property rights had been transferred to associations, associations had themselves become politically legitimate, and the combination had helped foster modern political economy. The corporation, once the derivative tool of the state, had become its rival, and the successes of the autonomous corporate management turned the basis for belief in an individualist conception of property on its head. The protests of modern legists notwithstanding, the business corporation had become the quintessential economic man. ${ }^{110}$

106. Mark, supra note 104 , at 1443.

107. Id. at 1475 .

108. Id. at 1476 .

109. Id. at 1475 .

110. Id. at 1482-83. 
Theories of rationality, naturalness, and the "good," presumed to be grounded in the nature of "man," may in reality be taking their notions of human essence not from "natural man" but from business corporations.

Ambivalence about personification, especially the personification of abstractions, has in fact permeated not only legal but also literary history. Nervousness about the agency of the personified corporation echoes the nervousness Enlightenment writers felt about the personifications dreamed up by the poets. As Steven Knapp puts it in his book Personification and the Sublime:

Allegorical personification - the endowing of metaphors with the agency of literal persons-was only the most obvious and extravagant instance of what Enlightenment writers perceived, with a mixture of admiration and uneasiness, as the unique ability of poetic genius to give the force of literal reality to figurative "inventions." More important than the incongruous presence of such agents was their contagious effect on the ostensibly literal agents with which they interacted. ${ }^{111}$

The uncanniness of the personification, then, was derived from its way of putting in question what the "natural" or the "literal" might be.

What the personification of the corporation ends up revealing, paradoxically enough, is that there is nothing "natural" about the natural person often taken as its model. The natural person, far from being a "given," is always the product of a theory of what the given is. This point may be made more clearly through an extreme version of corporate personhood. In a study of corporate rights, Meir DanCohen goes so far as to create the notion of a "personless corporation," a corporate "person" entirely controlled by computers, which would nevertheless still possess a "will" and a "personhood" of its own. ${ }^{112}$ Similarly, we might now ask how it has come to seem "natural" that the "natural person" with which the corporate person is compared is somehow always a "genderless person"; that unnatural genderless person who serves to ground both anthropomorphism and rational choice.

We have finally come back to the question of whether there is a difference between anthropomorphism and personification, which arose at the end of the discussion of the essay by Paul de Man. It can now be seen that everything hangs on this question. Anthropomorphism, unlike personification, depends on the givenness of the essence

111. STEVEn KNAPP, PERSONIFICATION AND THE SUblime 2 (1985).

112. MEIR DAN-COHEN, RIgHTS, PERSONS, AND ORganizations: A Legal THEORY For BUREAUCRATIC SOCIETY 46-51 (1986). 
of the human; the mingling of personifications on the same footing as "real" agents threatens to make the uncertainty about what humanness is come to consciousness. Perhaps the loss of unconsciousness about the lack of humanness is what de Man was calling "true 'mourning." 113 Perhaps the "fallacious lyrical reading of the unintelligible" is exactly what legislators count on lyric poetry to provide: the assumption that the human has been or can be defined. The human can then be presupposed without the question of its definition being raised as a question-legal or otherwise. Thus the poets truly would be, as Shelley claimed, the "unacknowledged legislators of the world," 114 not because they covertly determine policy, but because it is somehow necessary and useful that there be a powerful, presupposable, unacknowledgment. But the very rhetorical sleight of hand that would instate such an unacknowledgment is indistinguishable from the rhetorical structure that would empty it. Lyric and law are two of the most powerful discourses that exist along the fault line of this structure.

113. DE MAN, supra note 8, at 262 .

114. Percy Bysshe Shelley, A Defense of Poetry, in CrITICAL TheORY SinCE PLATo, supra note 15 , at 515,529 . 